https://journal.uwgm.ac.id/index.php/abdimasmahakam

E-ISSN: 2549-5755

Januari 2020, Vol. 4 No. 01

Received: Agustus 2019

Accepted: Desember2019

Published: Januari 2020

Article DOI: http://dx.doi.org/ 10.24903/jam.v4i1.775

\title{
Pelatihan Manajemen Usaha dan Pengelolaan Keuangan pada Kelompok Tani Kopi Desa Solor Kabupaten Bondowoso
}

\author{
Galih Wicaksono \\ Universitas Jember \\ galih.fisip@unej.ac.id \\ Tree Setiawan Pamungkas \\ Universitas Jember \\ tree.sp.fisip@unej.ac.id
}

\begin{abstract}
Abstrak
Terdapat berbagai permasalahan yang dihadapi oleh kelompok tani kopi terkait manajemen usaha dan pengelolaan kopi yang dilakukan oleh masyarakat Desa Solor Kecamatan Cermee Kabupaten Bondowoso yang meliputi : pembuatan pengemasan kopi dibuat secara sederhana dan seadanya saja dengan menggunakan kantong plastik, kedua mitra tidak memiliki pemahaman yang baik tentang desain kemasan kopi yang menarik, higienis, dan bernilai jual, pemasaran kopi hanya memenuhi kebutuhan lokal saja, modal pengembangan usaha yang terbatas, dan pengelolaan keuangan yang masih kacau. Berdasarkan beberapa permasalahan yang dihadapi oleh kedua mitra, tim Pelaksana PKM akan memberikan solusi sebagai berikut: pelatihan dan simulasi teknik pembuatan desain pengemasan kopi, pelatihan dan simulasi manajemen pemasaran kopi secara komprehensif, pelatihan dan simulasi pembuatan proposal kelayakan usaha dan bisnis usaha kopi, dan pelatihan dan simulasi penyusunan laporan keuangan usaha kopi. Dengan adanya beberapa intervensi yang dilakukan oleh Tim PKM, diharapkan mampu meningkatkan kapasitas dalam manajemen usaha dan pengelolaan keuangan yang dilakukan oleh petani kopi.
\end{abstract}

Kata Kunci: Kelompok Tani Kopi; Manajemen Usaha; Pengelolaan Keuangan.

\section{Pendahuluan}

Desa Solor merupakan salah satu desa yang ada di Kecamatan Cermee. Kecamatan Cermee sendiri terletak pada perbatasan antara Kabupaten Bondowoso dengan Kabupaten Situbondo. Kelompok tani kopi yang ada di Desa Solor menghasilkan kopi robusta yang memiliki rasa yang khas dibandingkan kopi yang lain. Terdapat beberapa petani kopi produktif yang ada di Desa Solor, diantaranya adalah Bapak Fauzul Muttaqin dan Bapak Iksan. Bapak Fauzul Muttaqin mengelola lahan kopi seluas 0,5 ha, serta menghasilkan kopi sebesar $350 \mathrm{~kg}$ kopi. Sedangkan Bapak Iksan juga mengelola lahan kopi seluas 0,5 ha, serta menghasilkan kopi sebesar $300 \mathrm{~kg}$ kopi.

Program Kemitraan Masyarakat yang dilakukan bermitra dengan kedua petani kopi tersebut, yaitu Bapak Fauzul Muttaqin (sebagai mitra 1) dan Bapak Iksan (sebagai mitra 2). Lingkup kegiatan kedua mitra tersebut secara garis besar dibagi menjadi dua aspek, yaitu kegiatan 
pengolahan kopi dan kegiatan pemasaran kopi. Kegiatan pengolahan kopi dimulai dari pemeliharaan komoditas kopi yang meliputi pemupukan, pemanenan, sampai dengan penanganan pasca panen. Sedangkan kegiatan pemasaran kopi dimulai dari penghitungan harga jual dan menjual kopi kepada masyarakat sekitar Desa Solor.

Kedua mitra melakukan pemanenan kopi sekali dalam setahun, yaitu mulai awal petik pada bulan Juni dan berakhir pada bulan September. Dalam setahun kedua mitra rata-rata menghasilkan kopi sebesar 300 - $350 \mathrm{~kg}$. Pada saat panen raya, harga biji kopi cenderung di bawah harga standar sehingga merugikan petani, yaitu pada harga Rp 18.000 , - $/ \mathrm{kg}$. Sedangkan apabila tidak musim panen, harga biji kopi relatif standar yaitu pada tingkat harga Rp 22.000, -/kg. Kedua mitra menghasilkan kopi robusta.

Program Kemitraan Masyarakat (PKM) ini ditujukan untuk membantu memecahkan beberapa masalah yang dihadapi oleh kedua mitra. Berdasarkan pengamatan dan wawancara yang dilakukan oleh tim Program Kemitraan Masyarakat dengan kedua mitra, maka dapat diperoleh data bahwa beberapa permasalahan utama yang dihadapi oleh kedua mitra berkaitan dengan usaha kopi, antara lain terkait dengan manajemen usaha dan pengelolaan keuangan.

Beberapa permasalahan yang terkait dengan manajemen usaha, antara lain: Permasalahan pertama, pembuatan pengemasan kopi dibuat secara sederhana dan seadanya saja dengan menggunakan kantong plastik. Hal ini dikarenakan kedua mitra tidak mempunyai alat pengemasan kopi yang bersifat modern. Permasalahan kedua, para mitra tidak memiliki pemahaman yang baik tentang desain kemasan kopi yang menarik, higienis, dan bernilai jual. Hal ini dikarenakan kedua mitra selama ini kemasannya bersifat tradisional dan dilakukan secara turun-temurun, yaitu hanya menggunakan kemasan plastik saja tanpa adanya kemasan yang memadai. Permasalahan ketiga, Pemasaran kopi hanya memenuhi kebutuhan lokal saja, yaitu di Desa Solor, wilayah Kecamatan Cermee, serta di Kabupaten Bondowoso. Kedua mitra belum memikirkan dengan serius untuk menembus pangsa pasar yang lebih luas, misalkan untuk masuk ke pangsa pasar Eks-Karesidenan Besuki dan Provinsi Jawa Timur.

Lebih lanjut, beberapa permasalahan yang terkait dengan pengelolaan keuangan antara lain masalah kempat berhubungan dengan modal dalam pengembangan usaha yang terbatas. Hal ini dikarenakan selama ini modal dalam usaha kopi sebagian besar berasal dari uang pribadi dan uang keluarga saja. Adanya modal yang terbatas, tentu saja menyebabkan usaha tidak berkembang dengan baik. Permasalahan kelima, pengelolaan keuangan yang masih kacau. Hal ini dikarenakan kedua mitra tidak mencatat dengan baik berapapun nominal rupiah pemasukan dan pengeluaran yang berkaitan dengan usaha kopi.

Berdasarkan beberapa permasalahan yang dihadapi oleh kedua mitra, maka perlu adanya intervensi dari Tim Program Kemitraan Masyarakat dalam mengentaskan permasalahan terkait pengelolaan usaha kopi. Dengan adanya beberapa intervensi, maka diharapkan permasalahan dapat diatasi dan mampu meningkatkan nilai usaha bagi para petani kopi di Desa Solor, Kecamatan Cermee, Kabupaten Bondowoso.

\section{Metode}

Untuk mengatasi persoalan yang dihadapi oleh kedua mitra, digunakan metode pelaksanaan yang diuraikan pada beberapa tahapan, meliputi pendanaan untuk hibah peralatan, pelatihan dan simulasi, pendampingan, dan evaluasi kegiatan. Secara rinci metode pelaksanaan yang akan dilakukan oleh Tim Program Kemitraan Masyarakat (PKM) adalah sebagai berikut: 


\section{(A) ABDIMAS \\ https://journal.uwgm.ac.id/index.php/abdimasmahakam}

E-ISSN: 2549-5755

Januari 2020, Vol. 4 No. 01

\section{Pelatihan dan Simulasi}

Kegiatan pelatihan dan simulasi yang akan dilakukan adalah: 1) pelatihan dan simulasi teknik pembuatan desain pengemasan kopi yang menarik, higienis, dan memiliki nilai pasar, 2) pelatihan dan simulasi manajemen pemasaran kopi secara komprehensif menggunakan media offline maupun online, dengan dibekali berbagai teknik dan strategi pemasaran produk kopi, 3) pelatihan dan simulasi pembuatan proposal kelayakan usaha dan bisnis bidang kopi, serta 4) memberikan pelatihan dan simulasi penyusunan laporan keuangan usaha kopi. Setelah dilakukan pelatihan, kedua mitra diberikan kesempatan untuk melakukan simulasi secara langsung untuk mengatasi permasalahan yang dihadapi di lapangan, sehingga diharapkan kegiatan ini akan efektif dan tepat sasaran untuk mengatasi masalah yang dihadapi oleh kedua mitra.

\section{Pendampingan}

Kegiatan pendampingan diperlukan untuk memantau agar aktifitas pelatihan dan simulasi yang telah dilakukan dapat terlaksana sesuai dengan target yang telah ditentukan, yaitu untuk memecahkan beberapa permasalah yang dihadapi oleh kedua mitra. Dengan adanya pendampingan, maka diharapkan untuk memastikan bahwa kedua mitra dapat mendesain pengemasan kopi yang menarik dan memiliki nilai jual ke pasar, mitra dapat melakukan pemasaran secara offline maupun online dengan memaksimalkan beberapa media pemasaran serta berbagai jenis teknik dan stretagi pemasaran produk. Lebih lanjut, pendampingan dilakukan untuk memastikan bahwa kedua mitra dapat membuat proposal kelayakan usaha dan bisnis di bidang kopi, serta mampu menyusun laporan keuangan secara efektif dan efisien.

\section{Evaluasi}

Untuk menilai keberhasilan kegiatan Program Kemitraan Masyarakat (PKM), maka akan dilakukan evaluasi kegiatan pada saat awal kegiatan dan akhir kegiatan. Evaluasi dilakukan dengan cara : 1) membandingkan tingkat keterampilan mitra dalam melakukan desain kemasan kopi antara sebelum dan sesudah pelatihan, 2) membandingkan pangsa pasar kopi antara sebelum dan sesudah adanya kegiatan, 3) membandingkan keterampilan mitra dalam membuat proposal kelayakan usaha dan bisnis kopi antara sebelum dan sesudah kegiatan pelatihan, serta 4) membandingkan keterampilan mitra dalam membuat laporan keuangan usaha kopi antara sebelum dan sesudah kegiatan pelatihan. Teknik membandingkan keterampilan dan pengetahuan kedua mitra dengan menggunakan kuesioner yang terukur, yang mencerminkan pengetahuan sebelum dan sesudah dilakukannya kegiatan pelatihan dan simulasi, sehingga dapat diketahui tingkat pemahaman kedua mitra mengenai materi pelatihan dan simulasi yang telah dilakukan.

\section{Hasil dan Pembahasan}

Program Kemitraan Masyarakat lebih rinci pelaksanaan kegiatan dapat dijelaskan sebagai berikut: Pelaksanaan pelatihan dan simulasi tentang kelayakan usaha dan bisnis bagi kelompok usaha dan petani kopi di Desa Solor Kecamatan Cermee. Kegiatan dilakukan dengan dilaksanakan di balai desa Solor. Kegiatan ini mengundang seorang pakar bidang kewirausahaan dan bisnis Penguatan dan kelompok usaha dan petani kopi di Desa Solor yang dilaksanakan dengan peserta kelompok usaha dan petani Kopi di desa solor, secara khusus 


\section{(A) ABDIMAS}

https://journal.uwgm.ac.id/index.php/abdimasmahakam

E-ISSN: 2549-5755

Januari 2020, Vol. 4 No. 01

mitra. Kegiatan dilakukan dengan metode musyawarah. Lokasi pelaksanaan kegiatan berada di Balai Desa Solor. Pelatihan dan simulasi pembuatan desain kemasan kopi juga bertempat di balai Desa Solor dengan peserta pelaku usaha kopi Desa Solor.

Pelatihan dan simulasi pemasaran produk olahan kopi dimulai dengan kegiatan pelatihan dan simulasi pemasaran diberikan kepada kelompok usaha dan petani kopi. Pemasaran penting dilakukan baik pada pelaku usaha dan petani kopi untuk meningkatkan akses pasar. Di mana desa solor memiliki keterbatasan akses pasar karena hambatan geografis, sehingga pelatihan pemasaran secara online di harapkan dapat meningkatkan akses pasar produk olahan kopi Desa Solor. Walaupun keterbatasan akses internet juga terjadi di Desa Solor. Simulasi pembuatan kemasan proiduk kopi dan pengelolaan pemasaran online dengan praktek langsung di lapangan menggunakan media teknologi informasi yang tersedia. Setelah dilakukan pelatihan dan simulasi yang didampingi dengan ahli pembuatan kemasan dan pengelolaan pemsaran online, maka pada tahap selanjutnya dilakukan simulasi untuk mengukur dan memastikan bahawa mitra serta para pengusaha dan petani kopi di Desa Solor mampu melakukan secara mandiri serta mengaplikasikannya dalam menjalankan usaha setalah kegiatan PKM berakhir.

Intervensi yang dilakukan oleh tim PKM telah mampu meningkatkan kemampuan para mitra dalam Pengemasan kopi yang menjadi lebih rapi dan higienis. Pengemasan kopi akan terlihat lebih menarik dan memiliki nilai jual ke pasar. Hal ini dikarenakan adanya peningkatan pengetahuan dan keterampilan mitra dalam pembuatan desain pengemasan kopi. Peningkatan jangkauan pemasaran, yang semula dipasarkan untuk memenuhi kebutuhan lokal, nantinya akan meluas pangsa pasarnya merambah sampai dengan pasar di wilayah Eks-Karesidenan Besuki. Peningkatan pengetahuan dan keterampilan mitra dalam mendatangkan modal dari investor maupun hibah dari pemerintah, yaitu dengan cara membuat proposal kelayakan usaha dan bisnis kopi yang memiliki nilai jual dan dapat meyakinkan investor dan pemerintah daerah, pemerintah provinsi, maupun pemerintah pusat. Peningkatan pengetahuan dan keterampilan mitra dalam penyusunan laporan keuangan usaha kopi, sehingga mitra dapat mengelola keuangan dengan lebih efektif dan efisien.

\section{Simpulan dan rekomendasi}

Berdasarkan beberapa solusi atas pemecahan masalah yang berkaitan dengan manajemen usaha dan pengelolaan keuangan, dapat disimpulkan bahwa kegiatan PKM telah menghasilkan nilai tambah bagi mitra sebagai berikut : Pengemasan kopi menjadi lebih rapi dan higienis. Hal ini dikarenakan adanya alat sealar untuk pengemas kopi, Pengemasan kopi terlihat lebih menarik dan memiliki nilai jual ke pasar, Peningkatan jangkauan pemasaran, yang semula dipasarkan untuk memenuhi kebutuhan lokal, menjadi meluas pangsa pasarnya merambah sampai dengan pasar di wilayah Eks-Karesidenan Besuki, Peningkatan pengetahuan dan keterampilan mitra dalam mendatangkan modal dari investor maupun hibah dari pemerintah, serta Peningkatan pengetahuan dan keterampilan mitra dalam penyusunan laporan keuangan usaha kopi, sehingga mitra dapat mengelola keuangan dengan lebih efektif dan efisien.

Rekomendasi yang diberikan oleh Tim PKM akan adanya kegiatan ini adalah, hendaknya kegiatan seperti ini secara rutin dilakukan oleh Perguruan Tinggi maupun Pemerintah Daerah, 


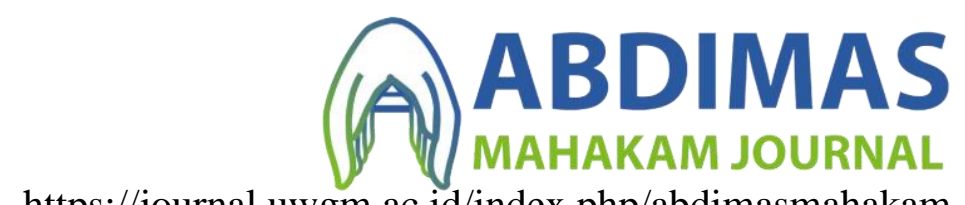

https://journal.uwgm.ac.id/index.php/abdimasmahakam

E-ISSN: 2549-5755

Januari 2020, Vol. 4 No. 01

sehingga akan membantu meningkatkan kemajuan usaha kecil kopi, serta mendukung pertumbuhan ekonomi yang berbasis potensi local daerah. 


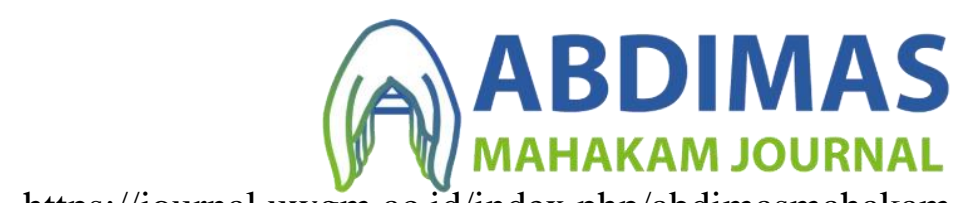

https://journal.uwgm.ac.id/index.php/abdimasmahakam

E-ISSN: 2549-5755

Januari 2020, Vol. 4 No. 01

\section{Daftar Pustaka}

BPS Kabupaten Bondowoso. 2015. Statistik Daerah Kecamatan Cermee 2015. Bondowoso.

Jayanti, Ni Ketut Dewi Ari, dkk. 2016. Pemanfaatan Teknologi Informasi dalam Meningkatkan

Nilai Jual dan Pemasaran UKM Kopi Bali. Majalah Aplikasi Ipteks Ngayah. Vol. 7 No.2 Desember 2016.

Universitas Jember. 2016. Pengembangan Kopi Rakyat Menuju Sistem Organik Guna

Meningkatkan Kesejahteraan Masyarakat. Roadmap RIP Universitas Jember 2016- 2020.

Jember. 